REFERENCES

1. Babor R, Talbot M, Tyndal A. Treatment of upper gastrointestinal leaks with a removable, covered, self-expanding metallic stent. Surg Laparosc Endosc percutaneous Tech 2009; 19:e1-e4

2. Da Costa Martins B, Medrado BF, de Lima MS, Retes FA, Kawaguti FS, Pennacchi CMPS, Maluf-Filho F. Esophageal metallic stent fixation with dental floss: a simple method to prevent migration. Endoscopy 2013; 45(E1).

3. Dasari BVM, Neely D, Kennedy A, Spence G, Rice P, Mackle E Epanomeritakis $E$. The role of esophageal stents in the management of esophageal anastomotic leaks and benign esophageal perforations. Ann Surg 2014; 259(5):852-860.

4. Freeman RK, Ascioti AJ, Wozniak TC. Postoperative esophageal leak management with the Polyflex esophageal stent. J Thorac Cardiovasc Surg 2007; 133:333-8.

5. Hirdes MMC, Vleggaar FP, Van Der Linde $K$, Willems M, Totté ER, Siersema PD. Esophageal perforation due to removal of partially covered self-expanding metal stents placed for a benign perforation or leak. Endoscopy 2005; 43:925.

6. Jacob CE, Bresciani CJC, Gama-Rodrigues JJ, Yagi OK, Mucerino DR, Zilberstein B, Cecconello I. Behavior of gastric cancer in Brazilian population. ABCD Arq Bras Cir Dig 2009; 22(1): 29-32.

7. Salminen P, Gullichsen R, Laine S. Use of self-expandable metal stents for the treatment of esophageal perforations and anastomotic leaks. Surg Endosc 2009; 23:1526-30.

8. Van Boeckel PGA, Dua KS, Weusten BL a M, Schmits RJH, Surapanen $\mathrm{N}$, Timmer R, et al. Fully covered self-expandable metal stents (SEMS) partially covered SEMS and self-expandable plastic stents for the treatment of benign esophageal ruptures and anastomotic leaks. BMC Gastroenterol 2012; 12(1):12-19.

9. Vanbiervliet G, Filippi J, Karimdjee BS, Venissac N, Iannelli A, Rahili A. The role of clips in preventing migration of fully covered metallic esophageal stents: a pilot comparative study. Surg Endosc 2012; 26(1):53-9.

10. Zilberstein B, Da Costa Martins B, Jacob CE, Bresciani CJC, Lopasso FP, DeCleva R, Pinto Júnior PE, Ribeiro Júnior U, Perez RO, Gama-Rodrigues JJ. Complications of gastrectomy with lymphadenectomy in gastric cancer. Gastric Cancer 2004; 7(4):254-259.

\section{ABCDDV/1130}

$A B C D$ Arq Bras Cir Dig Letter to the Editor 2015;28(3):218

DOI: /10.1590/S0102-67202015000300019

\section{ASSOCIATING LIVER RADIOFREQUENCY AND PORTAL VEIN LIGATION FOR STAGED HEPATECTOMY}

\author{
Associação de radiofrequência hepática e ligadura da veia \\ porta por hepatectomia regrada
}

Fábio Luiz WAECHTER ${ }^{1}$, Rinaldo Danesi PINTO², Felipe KOLESKI ${ }^{2}$, José Artur SAMPAIO ${ }^{1}$, Uirá Fernandes TEIXEIRA ${ }^{1}$

From the ${ }^{1}$ Unidade de Cirurgia Digestiva, Universidade Federal de Ciências da Saúde de Porto Alegre, Santa Casa de Misericórdia de Porto Alegre, RS, e 2Unidade de Cirurgia Digestiva, Universidade Regional de Blumenau, Hospital Santa Catarina, Blumenau, SC ('Surgery Unit, Federal University of Health Sciences of Porto Alegre, Santa Casa de Misericórdia de Porto Alegre, RS, and ${ }^{2}$ Digestive Surgery Unit, Regional University of Blumenau, Santa Catarina Hospital, Blumenau, SC), Brazil

Financial source: none

\section{Correspondence:}

E-mail: uiraft@yahoo.com.br
Uirá Fernandes Teixeira
Received for publication: 14/08/2014 Accepted for publication: 26/03/2015

\section{INTRODUCTION}

hepatic surgery, bringing a new method which can greatly contribute do increase resectability in patients once outside of surgical therapy.

Surgical resection remains the treatment of choice for patients with primary and secondary liver tumors, representing the only chance to obtain long-term survival ${ }^{1}$. Nowadays, with improvements in surgical expertise, anesthesia and postoperative care, no limits due to number of lesions and location are of value as in the past ${ }^{5}$.

Since the original cited report, some technical changes in ALPPS procedure (Associating Liver Partition and Portal vein ligation for Staged Hepatectomy) were described. Despite the initial enthusiasm with the new technique, several centers worldwide showed that, when properly indicated, the morbidity related mainly to the first surgery is high ${ }^{2}$. The release of hepatic ligaments and the transection of the liver parenchyma when the division of segments III and IV is often responsible for increased blood loss, biliary fistula and high operative time.

Thus, based on our previous experience with the use of bipolar radiofrequency with cold needles (BRCN) in performing hepatectomies ${ }^{3}$, coupled with our enthusiasm with this new two-staged technique, we decided to replace the hepatic parenchyma transection by making two lines of denatured liver tissue by radiofrequency, isolating the future liver remnant (FLR) in a similar way of surgical transection, more quickly, easily, with no hepatic mobilization and less blood loss.

This is a report of an initial experience, which we call ALRPS - associating liver radiofrequency and portal vein ligation for staged hepatectomy.

\section{CASE REPORT}

We performed the procedure in a 62-year-old woman with colorectal liver metastasis affecting the right liver and segment IV, without extrahepatic disease. Preoperative hepatic volumetry estimated FLR of $180 \mathrm{~cm}^{3}$. In the first surgery, liver lobes were separated without hepatotomy or hepatic mobilization, only with two lines of denatured liver tissue made by BRCN (Figure 1). We did not use plastic bag; instead, we covered the liver with a bioresorbable membrane to protect it. The right portal vein was ligated, it was performed ablation of middle hepatic vein and a tubular drain was placed. No blood transfusion was required.

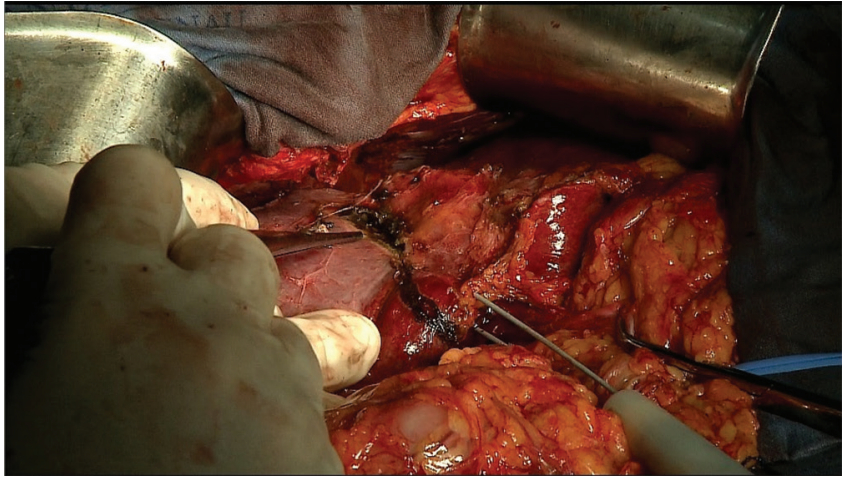

FIGURE 1 - Columns of denatured liver tissue made by radiofrequency

After 20 days, a CT volumetry showed that the left lateral liver lobe had increased to $464 \mathrm{~cm}^{3}$ approximately, a surprising hypertrophy of about $158 \%$. Relaparotomy was scheduled for the following day, with completion of an extended right hepatectomy (Figure 2). The postoperative course was uneventful. 


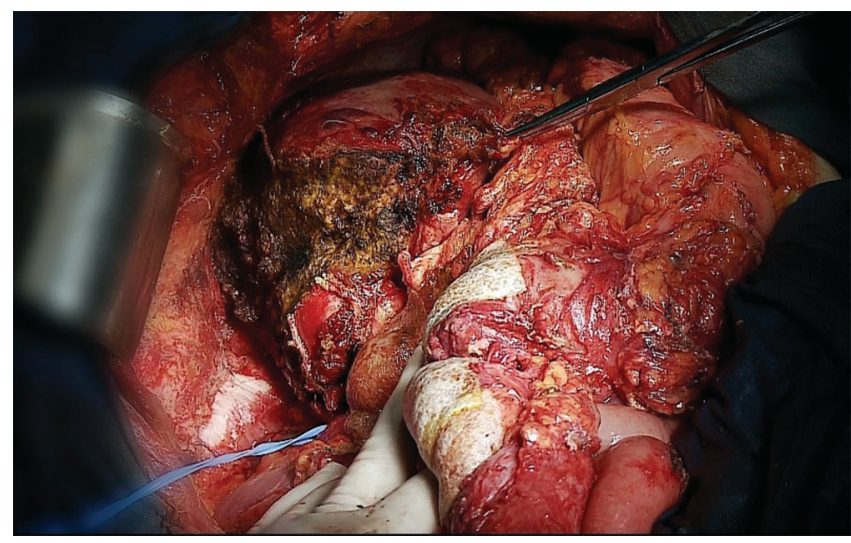

FIGURE 2 - Completion of extended right hepatectomy

\section{DISCUSSION}

With the advent of ALPPS, it became possible to achieve hypertrophy of FLR at $75 \%$ on average, in a quick way and over a mean period of nine days ${ }^{4}$. However, the authors reported high morbidity and mortality rates, particularly with regard to the initial surgery, with high rates of biliary fistula and intraoperative bleeding.

In our case, with the use of BRCN, there is no need for extensive hepatic mobilization. Thus, it is possible to perform the first procedure with a smaller abdominal incision. By making two columns of denatured liver tissue we eliminate the collateral branches between segments III and IV, with excellent results in the remnant liver hypertrophy (158\%). Furthermore, the occurrence of biliary fistula reduces significantly and, in the second surgery, the liver parenchyma can be cut with a scalpel in a quick and simple bloodless way.

We believe that necrosis induced by radiofrequency is a strong metabolic stimulus for migration of angiogenic factors and liver regeneration, adding an important contribution for FLR hypertrophy, since the increase in our report was far above the average of the initial work. It is not possible to draw conclusions from a single report. Further studies are needed, and is already underway our case series.

Thus, using BRCN in two stage hepatectomies represents a new technique to facilitate the procedure. Its use in conjunction with portal ligation, which we named ALRPS procedure, is easy to perform and has its own advantages, especially with regard to the reduction of surgical trauma of a complex hepatotomy and its complications (perioperative bleeding, prolonged surgical time), as well as obviate the dissection of hepatic ligaments.

\section{REFERENCES}

1. Adam R, Laurent A, Azoulay D et al. Two-stage hepatectomy: a planned strategy to treat irresectable liver umors. Ann Surg. 2000; 232:777-785.

2. Kokudo N, Shindoh J. How can we safely climb the ALPPS? Updates Surg. 2013, 65:175-177.

3. Sampaio JA, Waechter FL, Passarin TL et al. Is it possible to reduce the bleeding in hepatic resections without conducting total or partial vascular exclusion? Results of the use of bipolar radiofrequency with cold needles. Arq Bras Cir Dig. 2011; 24(2):159-163.

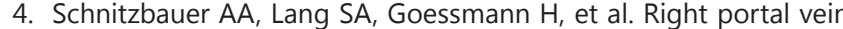
ligation combined with in situ splitting induces rapid left lateral liver lobe hypertrophy enabling 2-staged extended right hepatic resection in small-for-size settings. Ann Surg.2012;255:405-414.

5. Steele G, Ravikumar TS. Resection of hepatic metastases from colorectal cancer. Biologic perspective. Ann Surg 1989; 210: 127138.

\title{
GALLBLADDER CANCER AS INCIDENTAL FINDING IN TWO STAGE RESOLUTION OF GALLSTONE ILEUS
}

Câncer de vesícula biliar como achado incidental encontrado na resolução de íleo biliar em dois tempos

\author{
César Muñoz CASTRO'-3, Héctor Losada MORALES², \\ Marcelo Santelices BAEZA ${ }^{3}$.
}

From the ${ }^{1}$ Departamento de Cirugía, Universidad Católica del Maule, Talca; ${ }^{2}$ Departamento de Cirugía, Universidad de la Frontera, Temuco; ${ }^{3}$ Servicio de Cirugía, Hospital Regional de Talca, Talca, Chile

Financial source: none

Correspondence:

César Muñoz Castro

cesarmunozcastro@gmail.com

Received for publication: 16/09/2014 Accepted for publication: 26/03/2015

INTRODUCTION

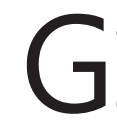
allstone ileus (GI) is a rare complication of biliary pathology when a bile stone from gallbladder or exceptionally from the main bile duct, cause an obstruction of the intestinal lumen ${ }^{10}$. Gallstone ileus incidence has remain constant through the years in 0,9 cases for 100.000 admissions/year ${ }^{6}$.

The diagnosis is usually difficult because of the abscense of specific symptoms, and sometimes by the partial remission of them during the migration of the bile stone through the intestinal lumen. This situation usually delays the consultation until there is greater compromise of the patient's general condition. The imaging studies, either simple radiology, ultrasound or computarized axial tomography of the abdomen are useful in the early diagnosis ${ }^{1}$. The initial treatment for GI is the reanimation and stabilization of the electrolite imbalance that might present on this patients and later perform the surgical resolution of the bowel obstruction.

The objective of this report is to present the finding of a gallbladder cancer in the two-stage resolution of a GI and discuss some aspects about the treatment of this disease.

\section{CASE REPORT}

Seventy-two years old female, with previous coronary heart disease, that look for medical assistance due to epigastric and right upper quadrant abdominal pain plus vomiting of a few days of evolution. Her physical exam showed tenderness on the right upper quadrant, without palpable mass. The laboratory test resulted with leukocytosis of $14900 \mathrm{cel} / \mathrm{mm}^{3}$, $C$ reactive protein of $104 \mathrm{mg} / \mathrm{dl}$ and all others were normal. A plain abdominal X-ray (Figure 1 ) and abdominal ultrasound were performed, and showed pneumobilia associated with an ovoid image in the mid jejunum with a change in the caliber of the bowel. With the diagnosis of GI a exploratory laparotomy was performed, with findings of two big bile stones at the mid jejunum. A longitudinal enterotomy was performed, with enterolithotomy and closure in one plane of suture. The patient evolved without complications and was discharched on the fifth day after the surgery. 